\title{
EFFECT OF SUPPLEMENTARY FEEDING UNDER DIFFERENT GRAZING CONDITIONS ON THE SKIN FOLLICLES AND HAIR COAT IN CAMELS RAISED AT HALAIEB SHALATEEN AND ABO-RAMAD TRIANGLE, EGYPT
}

\author{
A. S. A Abdou ${ }^{1}$, S. A. A Hekal ${ }^{1}$ and H. S. Khamis ${ }^{2}$ \\ 1- Wool Production and technology department, Desert Research Center, El- \\ Mataryia, Cairo, Egypt, 2- Animal and Poultry Nutrition Department, Desert \\ Research Center, El-Mataryia, Cairo, Egypt
}

\section{SUMMARY}

Twenty growing male one-humped camels aged 12 -18 months and average body weight of $166 \pm 19.73 \mathrm{~kg}$, raised at Shalateen Experimental Research Station (Desert Research Center) were used to examine their skin follicle growth and hair production in response to different levels of nutritional supplementation.

The study emphasizes the relationship between nutrient intake and product output reflects changes in the supply of substrates which are essential for follicle growth and fibre synthesis in the hair follicles. There is a significant increase in the values of $S / P$ ratio related to the increment in the supplementary feeding levels. Both primary and secondary follicle dimensions were affected by different seasons whereas the primary follicles only were affected by different levels of nutritional supplementations

Generally the increase in the internal diameter of the follicles in the dry season that was accompanied by a decrease in the follicles wall thickness could be in relation to the increased values of the fibre dimensions.

The adult fleece in camels composed of two main coats the outer and under coats, primary and secondary follicles respectively. The overall mean percentage of the under coat fibres increased from wet to dry season. Whereas, in case of the outer coat, only the fibres from type A and B (that with the largest medulla) were increased with the increased level of nutrition. The increase in the primary fibre diameter was more obvious than that in secondary fibres in relation to the subject of nutritional effects.

Keywords: Skin, hair coat, Camels, histology, supplementary feeding

\section{INTRODUCTION}

Camels are known to thrive fairly well under adverse conditions. They play an important role in the social and economic life of migratory pastoralists and nomads (Gauthier- Piltters and Dagg, 1981).

Issued by The Egyptian Society of Animal Production 
Shalateen camel's market is currently considered the main source of camel trade all over Egypt. Shalateen area is located at the Southern-Eastern Zone in Egypt, at the Red Sea down the cancer tropic, around $23.00{ }^{0} \mathrm{~N}$ and $35.00{ }^{0} \mathrm{E}$. There are numerous constraints that affect camel's performance, trading and marketing in this region. The most effective constraint is the erratic and short duration of rain precipitation which leads to long drought (from April up to October periods) (ElShaer et al., 1997). This constraint causes shortage of feed resources in that period which has a negative impact on camel production thus the activities and social life of residents.

Although seasonal changes in hair growth may be due to the circadian changes in photoperiod, they are also a result of the quantitative and qualitative changes in the feed available to the grazing animals in the course of the year and to changes in physiological state which tend to be associated with season.

The impact of nutrition on the hair growth of grazing animals has long been considered. The periods of poor pasture growth or quality are reflected in a reduction in total fleece growth per animal and per unit area of grazed land. As for all other forms of animal production, this relationship between nutrient intake and hair output reflects changes in the supply of substrates essential for fibre synthesis in the hair follicles, the skin fibre-producing factory.

This work aimed to study the effect of supplementary feeding in both grazing and drought seasons on the production of hair coat of camels to fulfil proper approaches for improving camel's performance and hair production in that region and consequently to achieve optimum social development. Also, some elementary determination of the structure and activity of skin follicles performed to assess the relevance of the present research to assessment of hair production.

\section{MATERIALS AND METHODS}

The present study was carried out on twenty growing male one-humped camels (Camelus dromedarius) aged 12-18 months with an average body weight of $166 \pm 19.73 \mathrm{Kg}$, raised at Shalateen Experimental Research Station (Desert Research Center) at the Southern-Eastern Zone in Egypt, at the Red Sea down the cancer tropic, around $23.00{ }^{0} \mathrm{~N}$ and $35.00{ }^{0} \mathrm{E}$. The experimental work was carried out during the period from December 2000 to November 2002. The camels were randomly allocated in four groups ( 5 camels each). The first group (control) grazed the local Panicum turgirdum as a basal ration. The other three groups also grazed on the same range while given traditional concentrate mixture (TCM) and ground date stones (GDS) at the rate of 1:1 (as supplementary feed equal to 50,75 and $100 \%$ of the energy maintenance requirements of dromedary camels according to the recommendation of Farid et al. (1996).

Camels of all groups were kept under the same managerial and hygienic conditions. All animals were kept under open pens; animals in each group were individually housed in pens. At the morning, supplementary feeding was offered for groups 2, 3 and 4 before grazing. The experimental animals were allowed to graze for $9 \mathrm{hrs}$, in wet season, and $11 \mathrm{hrs}$, in dry season, approximately. Fresh water produced from condensation station was available for 4 hrs, every day at all times of the study. 
Skin and hair samples were taken from the mid-side region of each animal twice per year; once at dry (July) and wet season (February). Skin specimens were fixed in calcium formol (Barker, 1958). Transverse sections were cut at 6-8 $\mu \mathrm{m}$ at the sebaceous gland level, then prepared and stained with hamatoxlyin and Eosin (Drury and Wallington, 1980).

From microscopical examination, the internal and external follicle diameters were measured and the wall thicknesses were calculated. A small tuft of fibres was sorted out into different fibre types according to their length and degree of medllation. The fibres that constituted the outer coat were those of the types A, B.C and D with 90, 70,50 , and $30 \%$ of their volume as medulla while fibres forming the under coat were sorted out separately according to Guirgis (1973). Fiber lengths of both outer and under coats were measured.

Data were analyzed using general linear model (GLM) according to (SAS, 1998) and differences between means were tested using Duncan's multiple range test according to Steel and Tourry (1990).

\section{RESULTS AND DISCUSSION}

Two kinds of follicles were found in the camel skin known as primary and secondary follicles. The primaries are usually the largest and are arranged in rows in the skin often of three primaries each (Fig. 1). The secondaries are more numerous and lie to one side of the primaries. The primary trio with its associated secondary follicles constitutes the follicle group, which is the unit of hair production (Fig. 1). The secondary being usually the smallest follicles tend to grow finer fibres than the primaries but the fundamental difference that distinguishes them in camel skin was that the primaries have a sweat gland and erector muscle, whereas the secondaries have neither of these (Fig. 2). Both types do, however, have sebaceous glands.

The average overall mean of secondary to primary follicle ratio S / P was approximately (4.907) in wet season and (4.819) in dry season, which lies between the ratios of Camels in the control group (3.833) and that fed with $100 \%$ supplementary feeding (5.386) (Table 1). There was no significant difference in the $\mathrm{S} / \mathrm{P}$ ratio between the animal having the different level of supplementation. Whereas, the control group showed a significant decrease in the values of S/ P ratio throughout the two seasons of the year (Table 1).

The changes of $\mathrm{S} / \mathrm{P}$ ratio were considerably attributed to the time as being due to seasonal changes must be postulated the disappearance and reappearance of secondary follicles (Burns, 1949). This seems to be unlikely, particularly during the short period when the $\mathrm{S} / \mathrm{p}$ dropped. Instead of completely disappearance of secondary follicles due to shedding, when follicles would be above the plane at which the count was made.

Follicle growth is ultimately under endocrine control and these hormones which influence follicular activity are in turn controlled by many environmental factors including photoperiod, temperature and nutrition (Speedy, 1992). 


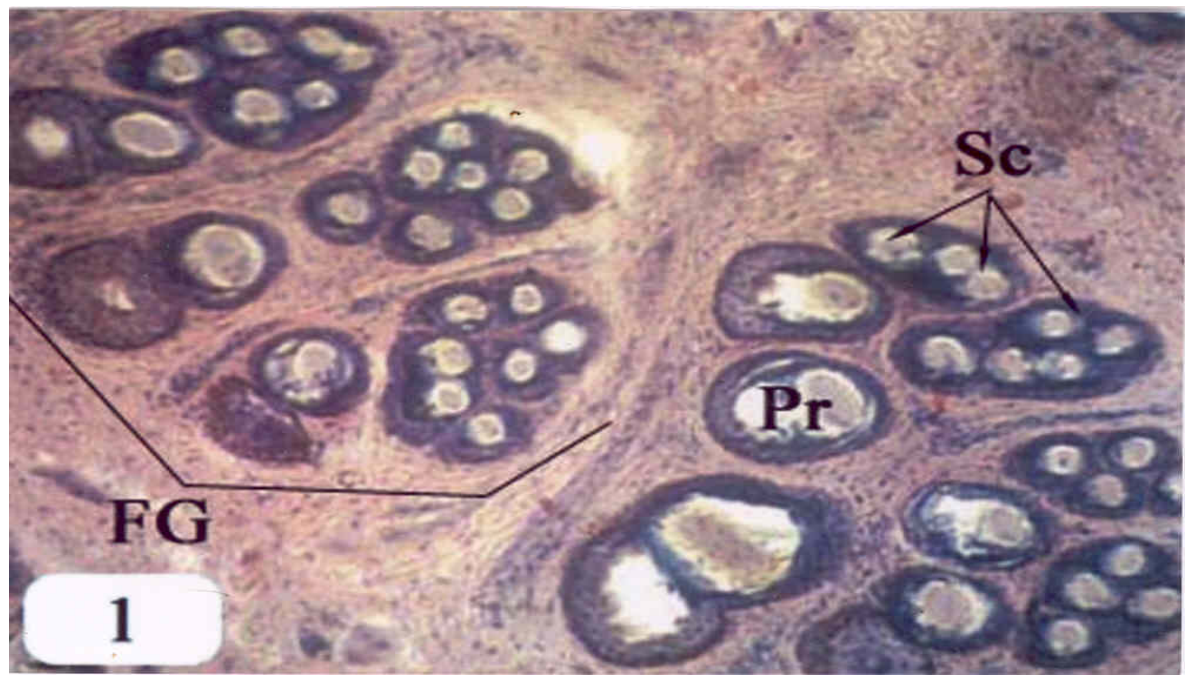

Fig. 1. Transverse section of Camel skin, showing hair follicles arranged in trio groups (FG). Pr, Primary follicles; Sc, Secondary follicles (HX.E.X100).

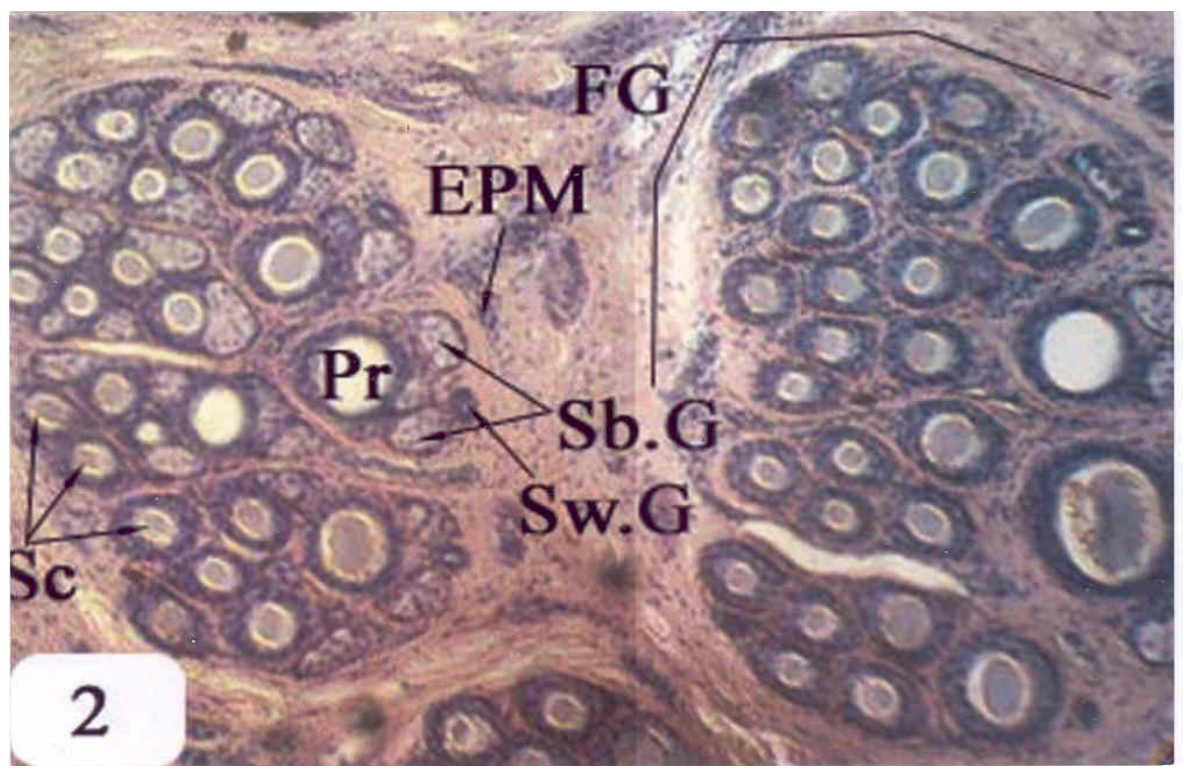

Fig. 2. Transverse section of Camel skin, showing the difference between primary and secondary follicles. Pr, Primary follicles; Sc, Secondary follicles; Sw.G, Sweat gland; Sb.G, Sebaceous gland; EPM, Erector pili muscle (HX.E.X100) 
Table 1. Average values of secondary to primary follicle ratio (S/P ratio $\pm \mathrm{SE}$ ) in both dry and wet seasons at different levels of nutritional supplementation

\begin{tabular}{|c|c|c|c|}
\hline Season & Dry season & Wet season & $\begin{array}{c}\text { Overall } \\
\text { mean }\end{array}$ \\
\hline Control & $3.99 \pm 0.439$ & $3.59 \pm 0.538$ & $3.833^{\mathrm{b}}$ \\
\hline Supplementation level & & & \\
\hline $50 \%$ & $4.81 \pm 0.439$ & $5.02 \pm 0.538$ & $4.912^{\mathrm{a}}$ \\
\hline $75 \%$ & $6.04 \pm 0.439$ & $4.84 \pm 0.538$ & $5.360^{\mathrm{a}}$ \\
\hline $100 \%$ & $4.77 \pm 0.439$ & $6.05 \pm 0.538$ & $5.386^{\mathrm{a}}$ \\
\hline Overall mean & $4.819^{\mathrm{a}}$ & $4.907^{\mathrm{a}}$ & \\
\hline
\end{tabular}

Also, energy intake can affect follicle activity and fibre production particularly at high levels of protein intake, as has been demonstrated by Reis et al. (1988). In the present study, both primary and secondary follicles dimensions were affected by different levels of nutrition in both the dry and wet seasons (Tables $2 \& 3$ ). Data in table (2) demonstrate increase in the internal diameter of the primary follicles in the dry season that was accompanied by a decrease in the follicle wall thickness.

On the other hand, the different levels of nutritional supplementation affected ultimately all primary follicle dimensions (Table 2). El-Sayed and AbouElEzz(1999) pointed out that the external and internal diameters of both primary and secondary follicles of camels were higher in summer than that in winter season, but the differences were not statistically significant except for the internal diameter of the secondary follicles $(\mathrm{P}<0.01)$.

The cell proliferation, as reviewed by Chapman and Ward (1979), occurs in the follicle bulb and in the outer root sheath along the entire length of the follicle.

In case of secondary follicles the different seasons had no significant effects on all follicle dimensions except the internal diameter of the follicle which increased in the dry season in relation to the increased values of the fibre diameters (Table 3).

The different levels of nutritional supplementation (Table 3), produced effect on the secondary follicles dimensions and fibres diameter. This confirms the results of similar work on Scottish feral goats by Russel (1990).

The substrates for the growth of both types of fibre are the same, and alterations in the relative growth rates of secondary and primary fibres are more likely to be due to differences between follicle type in the utilization of substrate and most likely in the transsulphuration of methionine to cystine (Speedy,1992). 
Table 2. Values of primary follicles dimensions $(\mu \mathrm{m})$ and their fibre diameters and medulla thickness in camels skin in both dry and wet seasons at different levels of nutritional supplementation ( Mean \pm SE)

\begin{tabular}{|c|c|c|c|c|c|c|}
\hline & $\begin{array}{l}\text { Group } \\
\text { Season }\end{array}$ & Control & $50 \%$ & $75 \%$ & $100 \%$ & $\begin{array}{c}\text { Overall } \\
\text { mean }\end{array}$ \\
\hline \multirow{2}{*}{$\begin{array}{l}\text { External } \\
\text { diameter }\end{array}$} & Dry & $\begin{array}{c}102.6 \pm \\
4.04\end{array}$ & $\begin{array}{c}110.8 \pm \\
4.04\end{array}$ & $\begin{array}{c}136.2 \pm \\
5.38\end{array}$ & $\begin{array}{c}106.5 \pm \\
4.68\end{array}$ & $111.665^{\mathrm{a}}$ \\
\hline & Wet & $\begin{array}{c}107.8 \pm \\
5.07\end{array}$ & $\begin{array}{c}110.6 \pm \\
4.33\end{array}$ & $\begin{array}{c}110.3 \pm \\
4.20\end{array}$ & $\begin{array}{c}110.9 \pm \\
5.22\end{array}$ & $109.988^{\mathrm{a}}$ \\
\hline \multicolumn{2}{|c|}{ Overall mean } & $104.608^{\mathrm{a}}$ & $110.677^{b}$ & $120.118^{\mathrm{a}}$ & $108.471^{b}$ & \\
\hline \multirow{2}{*}{$\begin{array}{l}\text { Internal } \\
\text { diameter }\end{array}$} & Dry & $\begin{array}{c}42.6 \pm \\
2.71\end{array}$ & $\begin{array}{c}56.5 \pm \\
2.71\end{array}$ & $\begin{array}{c}71.4 \pm \\
3.61\end{array}$ & $\begin{array}{c}61.5 \pm \\
3.14\end{array}$ & $55.947^{\mathrm{a}}$ \\
\hline & Wet & $\begin{array}{c}42.6 \pm \\
3.39\end{array}$ & $\begin{array}{c}52.2 \pm \\
2.89\end{array}$ & $\begin{array}{c}40.4 \pm \\
2.81\end{array}$ & $\begin{array}{c}57.9 \pm \\
3.49\end{array}$ & $47.723^{b}$ \\
\hline \multicolumn{2}{|c|}{ Overall mean } & $42.594^{\mathrm{c}}$ & $54.481^{\text {ab }}$ & $52.125^{b}$ & $59.904^{\mathrm{a}}$ & \\
\hline \multirow{2}{*}{$\begin{array}{l}\text { Wall } \\
\text { thickness }\end{array}$} & Dry & $\begin{array}{c}59.9 \pm \\
2.54\end{array}$ & $\begin{array}{c}54.6 \pm \\
2.54\end{array}$ & $\begin{array}{c}64.8 \pm \\
3.38\end{array}$ & $\begin{array}{c}61.5 \pm \\
3.12\end{array}$ & $55.676^{\mathrm{a}}$ \\
\hline & Wet & $\begin{array}{c}63.8 \pm \\
3.18\end{array}$ & $\begin{array}{c}58.3 \pm \\
2.72\end{array}$ & $\begin{array}{c}67.8 \pm \\
2.64\end{array}$ & $\begin{array}{c}57.9 \pm \\
3.47\end{array}$ & $47.723^{b}$ \\
\hline \multicolumn{2}{|c|}{ Overall mean } & $61.426^{\mathrm{ab}}$ & $56.326^{\mathrm{b}}$ & $66.649^{\mathrm{a}}$ & $59.904^{\mathrm{a}}$ & \\
\hline \multirow{2}{*}{$\begin{array}{c}\text { Fibre } \\
\text { diameter }\end{array}$} & Dry & $\begin{array}{c}42.6 \pm \\
2.69\end{array}$ & $\begin{array}{c}55.6 \pm \\
2.69\end{array}$ & $\begin{array}{c}71.4 \pm \\
3.58\end{array}$ & $\begin{array}{c}61.5 \pm \\
3.12\end{array}$ & $55.676^{\mathrm{a}}$ \\
\hline & Wet & $\begin{array}{c}42.6 \pm \\
3.37\end{array}$ & $\begin{array}{c}52.2 \pm \\
2.88\end{array}$ & $\begin{array}{c}40.4 \pm \\
2.80\end{array}$ & $\begin{array}{c}57.9 \pm \\
3.47\end{array}$ & $47.723^{b}$ \\
\hline \multicolumn{2}{|c|}{ Overall mean } & $42.594^{\mathrm{c}}$ & $54.002^{\mathrm{ab}}$ & $52.125^{\mathrm{b}}$ & $59.904^{\mathrm{a}}$ & \\
\hline \multirow{2}{*}{$\begin{array}{l}\text { Medulla } \\
\text { thickness }\end{array}$} & Dry & $\begin{array}{c}44.4 \pm \\
6.52\end{array}$ & $\begin{array}{c}43.2 \pm \\
5.32\end{array}$ & $\begin{array}{c}56.8 \pm \\
4.61\end{array}$ & $\begin{array}{c}40.3 \pm \\
2.87\end{array}$ & $44.577^{\mathrm{a}}$ \\
\hline & Wet & $\begin{array}{c}50.5 \pm \\
6.52\end{array}$ & $\begin{array}{c}49.1 \pm \\
6.03\end{array}$ & $\begin{array}{c}33.7 \pm \\
4.61\end{array}$ & $\begin{array}{c}35.5 \pm \\
3.02\end{array}$ & $38.573^{\mathrm{a}}$ \\
\hline \multicolumn{2}{|c|}{ Overall mean } & $47.422^{\mathrm{a}}$ & $45.801^{\mathrm{a}}$ & $45.258^{\mathrm{a}}$ & $37.999^{\mathrm{a}}$ & \\
\hline
\end{tabular}

Means with different letters within rows and column overall mean are different significantly at $\mathrm{P}<0.05$ 
Table 3. Values of secondary follicles dimensions $(\mu \mathrm{m})($ Mean $\pm \mathrm{SE}$ ) and their fibre diameters in camels skin in both dry and wet seasons at different levels of nutritional supplementation

\begin{tabular}{|c|c|c|c|c|c|c|}
\hline & $\begin{array}{l}\text { Group } \\
\text { Season }\end{array}$ & Control & $50 \%$ & $75 \%$ & $100 \%$ & $\begin{array}{c}\text { Overall } \\
\text { mean }\end{array}$ \\
\hline \multirow{2}{*}{$\begin{array}{l}\text { External } \\
\text { diameter }\end{array}$} & Dry & $62.1 \pm 10.83$ & $68.6 \pm 10.02$ & $77.6 \pm 12.70$ & $63.9 \pm 12.50$ & $72.423^{\mathrm{a}}$ \\
\hline & Wet & $66.8 \pm 14.29$ & $64.0 \pm 10.54$ & $63.8 \pm 10.36$ & $98.5 \pm 11.93$ & $67.654^{\mathrm{a}}$ \\
\hline \multicolumn{2}{|c|}{ Overall mean } & $63.840^{\mathrm{a}}$ & $66.450^{\mathrm{a}}$ & $69.250^{\mathrm{a}}$ & $82.070^{\mathrm{a}}$ & \\
\hline \multirow{2}{*}{$\begin{array}{l}\text { Internal } \\
\text { diameter }\end{array}$} & Dry & $18.29 \pm 0.522$ & $27.5 \pm 0.48$ & $32.9 \pm 0.61$ & $28.9 \pm 0.60$ & $26.350^{\mathrm{a}}$ \\
\hline & Wet & $22.6 \pm 0.69$ & $22.1 \pm 0.51$ & $20.0 \pm 0.49$ & $30.3 \pm 0.58$ & $23.451^{\mathrm{b}}$ \\
\hline \multicolumn{2}{|c|}{ Overall mean } & $19.874^{\mathrm{c}}$ & $24.937^{b}$ & $25.188^{b}$ & $29.633^{\mathrm{a}}$ & \\
\hline \multirow{2}{*}{$\begin{array}{c}\text { Wall } \\
\text { thickness }\end{array}$} & Dry & $43.6 \pm 0.64$ & $41.1 \pm 0.59$ & $44.4 \pm 0.75$ & $34.9 \pm 0.73$ & $41.167^{\mathrm{a}}$ \\
\hline & Wet & $44.2 \pm 0.84$ & $41.7 \pm 0.62$ & $43.7 \pm 0.61$ & $33.2 \pm 0.69$ & $40.751^{\mathrm{a}}$ \\
\hline \multicolumn{2}{|c|}{ Overall mean } & $43.781^{\mathrm{a}}$ & $41.384^{\mathrm{b}}$ & $43.993^{\mathrm{a}}$ & $34.044^{\mathrm{c}}$ & \\
\hline \multirow{2}{*}{$\begin{array}{c}\text { Fibre } \\
\text { diameter }\end{array}$} & Dry & $18.3 \pm 0.52$ & $27.5 \pm 0.48$ & $32.9 \pm 0.62$ & $28.9 \pm 0.60$ & $26.350^{\mathrm{a}}$ \\
\hline & Wet & $22.6 \pm 0.69$ & $22.1 \pm 0.51$ & $20.0 \pm 0.49$ & $30.3 \pm 0.58$ & $23.451^{\mathrm{b}}$ \\
\hline \multicolumn{2}{|c|}{ Overall mean } & $19.874^{\mathrm{c}}$ & $24.937^{b}$ & $25.188^{\mathrm{b}}$ & $29.633^{\mathrm{a}}$ & \\
\hline
\end{tabular}

Generally, the high rate of cell division and protein synthesis in the hair follicle might have a high sensitivity of the follicle processes and fibre growth to changes in the energy supply, protein, lipids, vitamins and minerals. The relative influence of these nutrients on fibre growth will depend on the pathways operating in the follicle cells.

Hynd and Master (2002) pointed out that at low levels of energy intake, maximum wool growth is reached at low levels of protein supply and further increases in wool growth then depend on energy intake.

The development of serum-free culture of hair follicles in minimal media (Philpott et al., 1990) paved the way for detailed studies of metabolism in actively growing follicles. These studies have shown that follicles have developed some unusual features of energy metabolism, including anaerobic glycolysis, glycogen metabolism, an active pentose phosphate pathway and glutaminolysis.

For normal fibre production, there must be synchrony between the two key processes of cell division and keratinization and follicles may function by pull (keratinization) as well as push (cell division) processes (Chapman \& Ward, 1979).

In camels, the adult fleece is composed of two coats. The outer coat, which is produced from the primary follicles, where its fibres are divided into four categories (A, B, C and D) according to their length and degree of medulla. The second coat type is the under coat which contain the fine fibres and is produced from the secondary follicles. Table (4) shows that the percentages of all fibre types of the outer coat were insignificantly affected by both dry and wet seasons. The overall mean percentage of under coat fibres was increased from wet season (12.372) to the dry one. (22.882). 
Table 4. Fibre type ratios in the coat of camels in both dry and wet seasons at different levels of nutritional supplementation $($ Mean \pm SE)

\begin{tabular}{|c|c|c|c|c|c|c|}
\hline Type & season & $100 \%$ & $75 \%$ & $50 \%$ & control & $\begin{array}{c}\text { Mean } \\
\text { of } \\
\text { season }\end{array}$ \\
\hline \multirow{3}{*}{ A } & Dry & $36.34 \pm 7.521$ & $29.74 \pm 7.521$ & $15.56 \pm 9.709$ & $21.90 \pm 8.406$ & $27.355^{\mathrm{a}}$ \\
\hline & Wet & $41.14 \pm 7.521$ & $28.76 \pm 7.521$ & $20.82 \pm 8.407$ & $31.40 \pm 8.407$ & $31.022^{\mathrm{a}}$ \\
\hline & Mean & $38.740^{\mathrm{a}}$ & $29.250^{\mathrm{ab}}$ & $18.571^{\mathrm{b}}$ & $26.560^{\mathrm{ab}}$ & \\
\hline \multirow{3}{*}{ B } & Dry & $25.92 \pm 8.887$ & $42.52 \pm 8.887$ & $30.60 \pm 11.473$ & $17.05 \pm 9.936$ & $29.541^{\mathrm{a}}$ \\
\hline & Wet & $43.4 \pm 8.887$ & $46.10 \pm 8.887$ & $65.00 \pm 9.935$ & $46.9 \pm 9.935$ & $42.300^{\mathrm{a}}$ \\
\hline & Mean & $34.690^{\mathrm{a}}$ & $45.310^{\mathrm{a}}$ & $33.114^{\mathrm{a}}$ & $28.975^{\mathrm{a}}$ & \\
\hline \multirow{3}{*}{$\mathrm{C}$} & Dry & $10.26 \pm 6.039$ & $12.60 \pm 6.039$ & $8.40 \pm 7.797$ & $9.67 \pm 6.752$ & $10.482^{\mathrm{a}}$ \\
\hline & Wet & $7.98 \pm 6.039$ & $15.00 \pm 6.039$ & $6.35 \pm 6.752$ & $0.00 \pm 6.752$ & $7.794^{\mathrm{a}}$ \\
\hline & Mean & $9.120^{\mathrm{a}}$ & $13.800^{\mathrm{a}}$ & $7.229^{\mathrm{a}}$ & $4.838^{\mathrm{a}}$ & \\
\hline \multirow{3}{*}{$\mathrm{D}$} & Dry & $10.62 \pm 3.283$ & $0.00 \pm 3.283$ & $3.63 \pm 4.238$ & $6.25 \pm 3.671$ & $5.235^{\mathrm{a}}$ \\
\hline & Wet & $0.00 \pm 3.283$ & $0.00 \pm 3.283$ & $0.00 \pm 3.671$ & $0.00 \pm 3.671$ & $0.000^{\mathrm{b}}$ \\
\hline & Mean & $5.310^{\mathrm{a}}$ & $0.000^{\mathrm{c}}$ & $1.557^{\mathrm{b}}$ & $3.125^{\mathrm{a}}$ & \\
\hline \multirow{3}{*}{ Outer } & Dry & $82.90 \pm 10.119$ & $85.92 \pm 10.119$ & $80.70 \pm 13.064$ & $53.72 \pm 11.314$ & $76.553^{a}$ \\
\hline & Wet & $92.58 \pm 10.119$ & $95.66 \pm 10.119$ & $84.37 \pm 11.314$ & $74.65 \pm 11.314$ & $87.628^{a}$ \\
\hline & Mean & $87.740^{\mathrm{ab}}$ & $90.790^{\mathrm{a}}$ & $82.800^{\mathrm{ab}}$ & $64.190^{\mathrm{b}}$ & \\
\hline \multirow{3}{*}{ Inner } & Dry & $17.10 \pm 10.204$ & $14.08 \pm 10.204$ & $16.00 \pm 13.173$ & $46.27 \pm 11.408$ & $22.882^{\mathrm{a}}$ \\
\hline & Wet & $7.42 \pm 10.204$ & $4.34 \pm 11.204$ & $15.62 \pm 11.408$ & $25.35 \pm 11.408$ & $12.372^{\mathrm{a}}$ \\
\hline & Mean & $12.260^{\mathrm{ab}}$ & $9.210^{\mathrm{b}}$ & $15.790^{\mathrm{ab}}$ & $35.810^{\mathrm{a}}$ & \\
\hline
\end{tabular}

Means with different letters within rows and columns overall mean are differed significantly at $\mathrm{P}<0.05$

The overall mean length of the fibres in both the outer and under coats of camels in the four experimental groups was not significantly affected by the different nutritional supplementation levels (Table 5). Whereas, only the fibers from type A and $\mathrm{B}$ were significantly affected in both dry and wet season from $(1.37 \pm 0.11$ and $0.92 \pm 0.12 \mu \mathrm{m})$ to $(1.84 \pm 0.12$ and $1.51 \pm 0.12 \mu \mathrm{m})$, respectively. The previous results could be explained due to the effect of nutrition in one season which would affect hair production in the next season and this was in agreement with the findings of Rowe et al. (1989) who working with young Merino sheep, observed a carry- over effect of supplementary feeding during summer and autumn on wool growth during winter. 
Table 5. Fibres length $(\mathrm{cm})$ and medulla type in the coat of camels in both dry and wet seasons at different levels of nutritional supplementation (Mean \pm SE)

\begin{tabular}{|c|c|c|c|c|c|c|}
\hline Type & Season & $100 \%$ & $75 \%$ & $50 \%$ & Control & $\begin{array}{c}\text { Mean of } \\
\text { season }\end{array}$ \\
\hline \multirow{3}{*}{ A } & Dry & $1.0 \pm 0.21$ & $1.8 \pm 0.21$ & $1.4 \pm 0.24$ & $1.3 \pm 0.24$ & $1.37 \pm 0.11^{\mathrm{b}}$ \\
\hline & Wet & $1.6 \pm 0.21$ & $1.9 \pm 0.21$ & $1.9 \pm 0.28$ & $1.9 \pm 0.24$ & $1.84 \pm 0.12^{\mathrm{a}}$ \\
\hline & Mean & $1.31 \pm 0.15^{\mathrm{b}}$ & $1.91 \pm 0.15^{\mathrm{a}}$ & $1.57 \pm 0.18^{\mathrm{ab}}$ & $1.60 \pm 0.17^{\mathrm{ab}}$ & \\
\hline \multirow{3}{*}{$\mathrm{B}$} & Dry & $0.70 \pm 0.24$ & $1.2 \pm 0.24$ & $0.8 \pm 0.26$ & $0.9 \pm 0.26$ & $.0 .92 \pm 0.12^{\mathrm{b}}$ \\
\hline & Wet & $1.4 \pm 0.24$ & $1.5 \pm 0.24$ & $1.5 \pm 0.31$ & $1.7 \pm 0.26$ & $1.51 \pm 0.12^{\mathrm{a}}$ \\
\hline & Mean & $1.03 \pm 0.17^{\mathrm{a}}$ & $1.35 \pm 0.17^{\mathrm{a}}$ & $1.42 \pm 0.20^{\mathrm{a}}$ & $1.31 \pm 0.19^{\mathrm{a}}$ & \\
\hline \multirow{3}{*}{$\mathrm{C}$} & Dry & $0.3 \pm 0.24$ & $0.7 \pm 0.24$ & $0.2 \pm 0.26$ & $0.6 \pm 0.26$ & $0.44 \pm 0.13^{\mathrm{a}}$ \\
\hline & Wet & $0.6 \pm 0.24$ & $0.5 \pm 0.24$ & $0.2 \pm 0.31$ & $0.0 \pm 0.26$ & $0.38 \pm 0.13^{\mathrm{a}}$ \\
\hline & Mean & $0.47 \pm 0.16^{\mathrm{a}}$ & $0.63 \pm 0.16^{\mathrm{a}}$ & $0.18 \pm 0.20^{\mathrm{a}}$ & $0.28 \pm 0.18^{\mathrm{a}}$ & \\
\hline \multirow{3}{*}{ Outer } & Dry & $0.7 \pm 0.18$ & $1.2 \pm 0.18$ & $0.8 \pm 0.20$ & $0.9 \pm 0.20$ & $0.91 \pm 0.10^{b}$ \\
\hline & Wet & $1.2 \pm 0.18$ & $1.3 \pm 0.18$ & $1.2 \pm 0.23$ & $1.2 \pm 0.20$ & $1.24 \pm 0.10^{\mathrm{a}}$ \\
\hline & Mean & $0.940 \pm 0.12^{\mathrm{a}}$ & $1.290 \pm 0.12^{\mathrm{a}}$ & $0.970 \pm 0.15^{\mathrm{a}}$ & $1.062 \pm 0.14^{\mathrm{a}}$ & \\
\hline \multirow{3}{*}{ Inner } & Dry & $0.6 \pm 0.25$ & $0.2 \pm 0.25$ & $0.7 \pm 0.28$ & $0.7 \pm 0.28$ & $0.51 \pm 0.14^{\mathrm{a}}$ \\
\hline & Wet & $0.4 \pm 0.25$ & $0.4 \pm 0.25$ & $0.7 \pm 0.33$ & $1.6 \pm 0.28$ & $0.70 \pm 0.14^{\mathrm{a}}$ \\
\hline & Mean & $0.460 \pm 0.18^{\mathrm{b}}$ & $0.300 \pm 0.18^{\mathrm{b}}$ & $0.685 \pm 0.22^{\mathrm{ab}}$ & $1.100 \pm 0.20^{\mathrm{a}}$ & \\
\hline
\end{tabular}

Norton et al. (1990) and Norton (1991) investigated the effects of many different feeding regimes and forms of supplementation on Cashmere production of Australian feral goats. Their nutritional treatments ranged from maintenance levels of feeding to the ad libtum feeding of Lucerne pellets, and have incorporated a wide range of protein intakes, including various protected protein supplements according to Ash and Norton (1984). In non of these experiments there was any evidence of a response in cashmere production or in fibre diameter when either the level or quality of feed was above that needed for the maintenance of live weight.

The fibres diameters in the coat tended to be higher in winter than in summer season and these results corresponded with the same measurements in histological studies in hair follicle by El-Sayed and Abou El-Ezz (1999). They also concluded that these differences were statistically non significant.

The evidence thus indicates that while secondary fibre growth may be reduced by relatively severe under nutrition, such as that imposed by Mc Gregor (1988) on goats, it is unresponsive in terms of increased weight or fibre diameter to the provision of any nutrients beyond those required for maintenance. This statement does not, however, apply to the primary outer coat fibres. Experiments by Ash \& Norton (1987) and Mc Gregor (1988) indicated no effect of nutrition on cashmere growth, and demonstrated substantial effects on guard hair production.

The increased nutritional level in the different experimental groups had no significant effect on the medulla thickness in the primary fibres of the outer coat (Table 2). McGregor (1984) reported that a lower level of nutrition was associated with an increased medulated fibre content of the fleece, although this is not found by later studies by Bigham et al. (1990) In a recent review of factors influencing the degree of medullation in mohair, Lupton et al. (1991) concluded that nutrition has 
little if any effect on the incidence of this undesirable characteristic. This was in agreement with the results on camels in the present study as shown by table (2).

Generally, it could be concluded that the group of camels that received a $75 \%$ nutritional supplementation level showed a more suitable hair production in comparison with the other groups even which had 100\% supplementation level. Although adequate supply of dietary protein or at least of the nitrogenous substrates from which microbial protein may be synthesized is essential for hair growth, it does not follow that the provision of additional protein in the diet will invariably result in increased hair production. Denney and Hogan (1987) pointed out that in sheep eating high protein diets there can be a substantial wastage of crude protein associated with high rumen ammonia concentration. This can appreciably reduce the quantity of amino acids absorbed and may limit wool growth.

It could be argued convincingly that in pastoral situation the main challenges are to improve digestibility and increase protein relative to volatile fatty acids in the products of digestion. Without correction of dietary deficiencies, manipulation of the rumen or of the animal's genome is unlikely to improve production and may even be detrimental (Speedy, 1992).

\section{REFERENCES}

Ash, A.T. and B.W. Norton, 1984. The effect of protein and energy intake on cashmere and body growth of Australian Cashmere goats. Proceedings of the Australian Society of Animal Production 15:247.

Ash, A. T. and B.W. Norton, 1987. Productivity of Australian cashmere goats grazing Pangola grass pastures and supplemented with untreated and formaldehyde treated protein meals. Australian Journal of Experimental Agriculture 27: 799-784.

Barker, J. R., 1958. Principles of biological technique. London, Meunchen, New York, John Wiley. Bancroft. J.D.

Bigham, M.L., M. Bown and G.B. Nicoll, 1990. The manipulation of kemp and medullation in the mohair fleece by breeding and management Proceeding $8^{\text {th }}$ Research conference, New Zealand 7pp.277-283.

Burns, M., 1949. Studies on the follicle population in relation to fleece changes in lambs of the English Leicester and Rommey Breeds. J. Agric. Sci.Camb.39:6479.

Chapman, R.E. and K.A. Ward, 1979. Histological and biochemical features of the wool fibre and follicle. In: Physiological and Environmental Limitations to wool growth. Black, J.L and Reis,P.J (Eds) University of New England, Armidale, Australlia, Pp.193-208.

Chapman,R.E., A.M. Downes and P.A. Wilson, 1980. Migration and keratinization of the cells in wool follicles. Australian Journal of Biological Sciences 33:587603.

Denney, G.D and J.P. Hogan, 1987. Digestion and wool production of sheep grazing grass/medic pasture in the low rainfall wheat belt. Temperature pastures their production, use and management. J. Lwheeler, C.T. Pearson, G. E. Robards (Eds), East Melbourne, Victoria Austrlia: Commonwealth Scientific and Industrial Research Organization, PP. 356-358. 
Drury, R.A.P. and E.A. Wallington, 1980. Carlton's Histological Technique $4^{\text {th }}$ Ed. Oxford, New York, Toronto, Oxford University Press.

El-Sayed, N. A. and S.S. Abou El-Ezz, 1999. Effect of season on thermo-respiratory response and skin traits in the dromedary camels under semi arid conditions. J. Agric. Sci. Mansura Univ., 24 (10):5437-5449.

El Shaer, H.M. 1997. Sustainable utilization of halophytic plant species as livestock fodder in Egypt. Proc. Inter. Conf. on "Water management, salinity and pollution control towards sustainable irrigation in the Mediterranean region". Sept. 22-26, 1997, Bary, Italy, PP. 171-184.

Farid, M.F.A., H.S. Khamis, H.M. Abou El-Nasr, M.H. Ahmed and S.M. Safinaz, 1996. Diet selection and food intake capacity of stall-fed sheep ,gouts and camels in relation to some physical properties of food and their potential digestion in the rumen .proc. of seminar on Recent Advances in small Ruminants Nutrition. Oct .24-26, Rabat, Morocco.

Hynd, P.I. and D.G Masters, 2002. Nutration and wool Growth. Department of Animal Science, Adelaide University, Roseworthy, South Autralia :CSIRO Livestock Industries, Wembley Western Australia, Pp 165-186.

Gauthier-Pilters, H. and A.I. Dagg, 1981. The camel its evolution ecology, behaviour and relationship to man. The University of Chicago Press, Chicago.

Guirgis, R. A., 1973. The study of variability of some wool traits in a coarse wool breed of sheep. J. Agric. Sci. Camb. 8: 233-238.

Lupton, C.J., F.A. Pfeiffer, and N.E. Blakeman, 1991. Medullation in mohair. Small Ruminant Research 5:357-365.

Mahgoub, A.S., M.M. Mefeerj and Y.S Ghanem 1999. A histological study of the hair follicles of the Saudi Arabian Camel Desert Inst. Bull., Egypt, 49, No 2:427447.

McGregor, B.A., 1984. Growth and fleece production of Angora withers grazing animal pastures. Proceedings of the Australian Society of Animal Production 15:715.

McGregor, B.A., 1988. Effects of different nutritional regimes on the productivity of Australian Cashmere goats and the partitioning of nutritients between Cashmere and hair growth. Australian Journal of Experimental Agriculture 28:459-467.

Norton, B.W., 1991. Management of Australian Cashmere goats for maximum fleece growth. Proceeding Cashmere Research Seminar, Ballina New South Wales department of Agriculture and Fisheries, Pp.28-41.

Norton. B.W., C. A. Wilds and J.W. Hales, 1990. Grazing management studies with Australian Cashmere goats. 1. Effects of stocking rate on the growth and fleece production of weaned goats grazing tropical pastures. Australian J. Exp. Agric. 30: 769-775.

Philpott, M.P., M.R. Green and T. Kealey, 1990. Human hair growth in vitro. J. Cell Sci., 97: 463-471.

Reis, P. T., D.A. Tunks and S.G. Munes, 1988. Relative importance of amino acids and energy for wool growth. Proceeding of the nutrition society of Australia. 13: 122.

Rowe, J.B., G. Brown, I.G. Raph, J. Ferguson and J.F. Wallace, 1989. Supplementary feeding of young Merino sheep grazing wheat stupple, with different amounts of Lupin oat or barley grains. Australian J. of Exp. Agric. 29: 29-35. 
Russel, A.J.F., 1990. Nutrition of cashmere Goats .In Scottish cashmere. The viable alternative. A.T.F. Russel (ed., Scottish cashmere Producers Association, Edinburgh, Pp. 32-46.

SAS, 1998. Statistical analysis system, STAT/ user's guide, release 603 ed. SAS Institute, Cary NC. U. S. A.

Speedy, A.W., 1992. Progress in Sheep and goats. A.J.F. Russel. The Macaulay land use Research Institute, Pentland field, Roslin, Midlothian, EH 26 6RF, UK, Pp. 235-255.

Steel, R.G.D. and J.H. Torrie, 1960. Principles and procedures of statistics. McGrawHill Book Co., N.Y.481pp. 
تأثير التظذية الإضافية تحت ظروف رعى مختلفة على حويصلات الجلا وغطاء الثعر فى جمال مثلث حلايب-

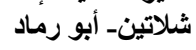
عائشة سيد عبده1، سامية عبد المجيد هيكل، حجازى سالم خميس2

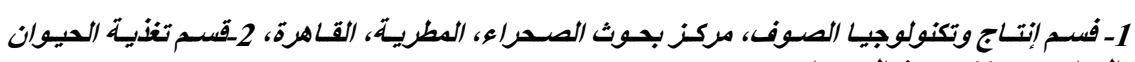
والدواجن، مركز بجوث الصحراء

أستخدم فى هذه الار اسـة عدد 20 من ذكور الإبل ذات أعمار تتر اوح من 12-18 شـهر لدراسـة تأثئير

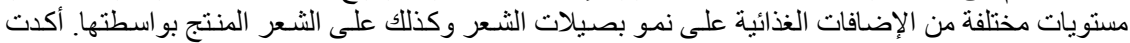

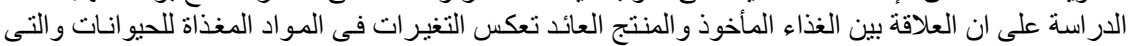

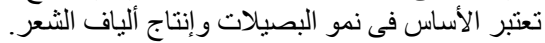

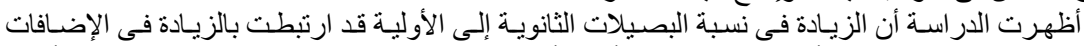

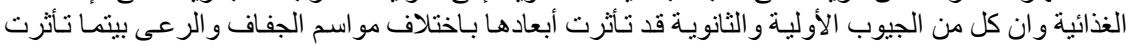

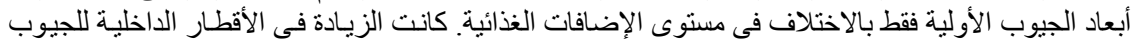

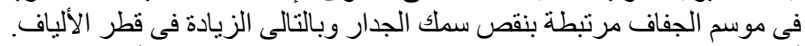

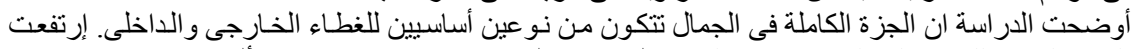

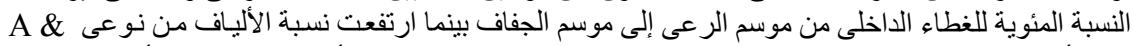

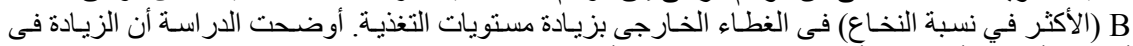
أقطار الألياف الأولية كان أكثر وضوحا عنها فى الألياف الثانوية عند تعرضها للمؤثرات الثيات الغذائية المختلفة. 